\title{
Penggunaan Benzil Amino Purin (BAP) pada Okulasi Jeruk Keprok (Citrus reticulata)
}

\author{
The Use of Benzyl Amino Purines (BAP) on Budding Mandarins \\ Nur Wahyu Sariningtias ${ }^{1}$, Roedhy Poerwanto ${ }^{1^{*}}$, dan Endang Gunawan ${ }^{2}$ \\ Diterima 4 Februari 2014/Disetujui 20 Agustus 2014
}

\begin{abstract}
Mandarins (Citrus reticulata) is one of the important fruit commodity in Indonesia. The problems that often arise in the development is the availability of healthy seedlings and in large numbers. The purpose of this research was to determine the effect of Benzyl Amino Purines (BAP) on the success of budding and bud growth on the plant mandarins Borneo Prima and Garut Dataran Rendah. This research was conducted at the Pasir Kuda Experimental Farm, Ciomas, Bogor in January to May 2013. This experiment was arranged in a randomized complete block design with two factors of the scions varieties (Borneo Prima and Garut Dataran Rendah) and the concentration of $B A P(0,5,10$, and $15 \mathrm{ppm})$, repeated 3 times so there were 24 experimental units. The research data was analyzed statistically using $F$ test at $5 \%$ and continued with DMRT test at 5\%. The results showed that the application of BAP at low concentration on the scions of the two varieties do not give significantly different results in the variable of success of budding and growth of plant shoots.
\end{abstract}

Keywords: bud, cytokinin, nutrition, rootstock, scion

\begin{abstract}
ABSTRAK
Jeruk keprok (Citrus reticulata) merupakan salah satu komoditas buah yang penting di Indonesia. Permasalahan yang sering muncul dalam pengembangan jeruk keprok adalah ketersediaan bibit yang sehat dalam jumlah banyak. Tujuan penelitian ini adalah untuk mengetahui pengaruh pemberian Benzil amino purin (BAP) terhadap keberhasilan okulasi dan pertumbuhan tunas pada tanaman jeruk keprok Borneo Prima dan Garut Dataran Rendah. Penelitian ini dilaksanakan di Kebun Percobaan Pasir Kuda, Ciomas, Bogor pada bulan Januari sampai bulan Mei tahun 2013. Penelitian disusun dalam rancangan kelompok lengkap teracak (RKLT) faktorial dengan dua faktor yakni varietas batang atas (Borneo Prima dan Garut Dataran Rendah) dan konsentrasi BAP $(0,5,10$, $15 \mathrm{ppm}$ ), diulang 3 kali sehingga terdapat 24 unit percobaan. Data hasil percobaan dianalisis secara statistika dengan uji F pada taraf nyata 5\% dan dilanjutkan dengan uji lanjutan DMRT pada taraf nyata 5\% untuk nilai yang berbeda nyata. Hasil penelitian menunjukkan bahwa pemberian BAP dengan konsentrasi rendah pada dua varietas batang atas jeruk keprok tidak memberikan hasil yang berbeda nyata pada peubah keberhasilan okulasi dan pertumbuhan tunas tanaman.
\end{abstract}

Kata kunci: batang atas, batang bawah, nutrisi, sitokinin, tunas

\section{PENDAHULUAN}

Jeruk keprok merupakan salah satu jenis jeruk berwarna jingga yang tumbuh baik di dataran tinggi. Beberapa varietas jeruk keprok komersial hasil seleksi Balitjestro dan dari Pemerintah Daerah yang sudah dilepas oleh Kementerian Pertanian antara lain Keprok Batu 55 berasal dari Batu (Jawa Timur), Keprok Garut (Jawa Barat), Keprok Pulung

\footnotetext{
${ }^{1}$ Departemen Agronomi dan Hortikultura, Fakultas Pertanian, Institut Pertanian Bogor

(Bogor Agricultural University), J1. Meranti, Kampus IPB Darmaga, Bogor 16680, Indonesia

Telp.\&Faks.62-251-8629353 e-mail: roedhy8@yahoo.co.id (*penulis korespondensi)

${ }^{2}$ Pusat Kajian Hortikultura Tropika (PKHT), Jl. Raya Pajajaran, Kampus IPB Baranangsiang, Bogor 16144, Indonesia

Telp. 0251-8326881,8382201 Faks.0251-8326881.e-mail ipbfruit@indo.net.id, fruit@ipb.ac.id

website http://www.pkht.or.id/, http://pkht.ipb.ac.id/
} 
(Jawa Timur), Keprok Tawangmangu (Jawa Tengah), Keprok Soe (Nusa Tenggara Timur), Keprok Tejakula (Bali), Keprok Madura, Keprok Borneo Prima (Kalimantan Timur) dan Keprok Trigas (Kalimantan Barat). Terbatasnya lahan di dataran tinggi yang cocok untuk pertanian menyebabkan pengembangan jeruk keprok tersebut terhambat. Saat ini ditemukan ada beberapa varietas jeruk keprok yang dapat dikembangkan di dataran rendah dan menghasilkan buah jeruk berwarna jingga.

Bergesernya selera masyarakat yang cenderung lebih menyukai jeruk berwarna jingga menyebabkan terjadinya peningkatan permintaan terhadap jeruk tersebut. Produksi jeruk berwarna jingga yang ada di Indonesia saat ini belum mampu memenuhi kebutuhan permintaan konsumen. Kondisi tersebut membuat Indonesia diserbu jeruk impor dari berbagai negara. Peningkatan impor jeruk berwarna jingga terjadi setiap tahunnya. Hal ini menempatkan Indonesia termasuk sebagai negara pengimpor jeruk terbesar kedua di ASEAN setelah Malaysia (Hardiyanto, 2012).

Berdasarkan Angka Tetap (ATAP) 2011 dari Direktorat Jenderal Hortikultura (2011), luas panen jeruk (jeruk siam/keprok dan jeruk besar) di Indonesia pada tahun 2011 adalah 51.69 ribu ha. Provinsi di Luar Jawa umumnya lebih mendominasi luas panen jeruk dibandingkan provinsi di Jawa. Tahun 2011 luas panen jeruk di luar Jawa sebesar 40.23 ribu ha $(77.83 \%)$, sedangkan di Jawa sebesar 11.46 ribu ha (22.17\%). Produksi jeruk di Indonesia pada tahun 2011 mencapai 1818949 ton dan mengalami penurunan pada tahun 2012 menjadi sebesar 1611784 ton (BPS, 2013).

Hardiyanto (2012), menyatakan agribisnis jeruk masih didominasi oleh jeruk Siam yang mencapai hampir 80\%. Luas pertanaman jeruk di dataran rendah, 60 persennya merupakan jeruk Siam. Sutopo (2012) menambahkan bahwa petani lebih senang menanam jeruk Siam karena lebih cepat berbuah dan produktivitasnya lebih tinggi. Di Jawa Barat, khususnya Bogor sedang dikembangkan beberapa varietas jeruk keprok yakni keprok Borneo Prima dan keprok Garut Dataran Rendah. Menurut Poerwanto et al. (2013), kedua varietas jeruk tersebut berpotensi untuk dikembangkan di dataran rendah. Bibit jeruk unggul bebas penyakit dibutuhkan dalam jumlah banyak untuk pengembangan tersebut. Salah satu metode perbanyakan bibit jeruk yang biasa digunakan adalah dengan okulasi. Perbanyakan tanaman secara komersial dengan metode okulasi secara besar-besaran perlu dilakukan untuk menunjang program tersebut.

Kenyataannya okulasi tidak dapat dilakukan setiap waktu, karena okulasi yang dilakukan pada saat kambium tidak sedang aktif membelah, biasanya mengalami kegagalan. Di daerah tropik seperti di Indonesia agak sulit untuk mengetahui aktivitas kambium. Penggunaan Benzil Amino Purin (BAP) diharapkan dapat mengurangi kegagalan okulasi, sehingga okulasi jeruk dapat dilakukan kapan saja.

Benzil Amino Purin (BAP) adalah zat pengatur tumbuh yang termasuk ke dalam jenis sitokinin yang dapat berperan untuk merangsang pembelahan sel. Pada perbandingan konsentrasi tertentu, BAP bersama hormon yang lain dapat merangsang pertumbuhan tunas tanaman. Namun, penelitian mengenai pengaruh pemberian BAP terhadap keberhasilan okulasi pada tanaman jeruk belum banyak dilakukan. Oleh karena itu, perlu dilakukan penelitian mengenai penggunaan BAP kaitannya untuk meningkatkan keberhasilan okulasi pada tanaman jeruk. Penelitian ini bertujuan untuk mengetahui pengaruh pemberian BAP terhadap keberhasilan okulasi dan pertumbuhan tunas pada tanaman jeruk keprok Borneo Prima dan jeruk Garut Dataran Rendah.

\section{BAHAN DAN METODE}

Penelitian dilaksanakan di Kebun Percobaan Pasir Kuda, Ciomas, Bogor pada bulan Januari sampai Mei 2013. Bahan tanaman yang digunakan adalah jeruk keprok Borneo Prima dan jeruk Garut Dataran Rendah sebagai batang atas untuk diambil mata tunasnya dan jeruk varietas RL sebagai batang bawah. Pada penelitian ini digunakan pula BAP sebagai perlakuan dan air bersih. Alat yang diperlukan untuk melaksanakan kegiatan tersebut meliputi alat-alat okulasi, baskom, gelas ukur, plastik penutup/pengikat, label, penggaris, alat tulis untuk mencatat, kamera, dan alat-alat lain yang menunjang dalam pelaksanaan kegiatan penelitian.

Penelitian ini menggunakan rancangan perlakuan faktorial dengan dua faktor yang disusun dalam rancangan kelompok lengkap teracak (RKLT). Faktor pertama adalah varietas batang atas, yakni Borneo Prima dan 
Garut Dataran Rendah. Faktor kedua adalah konsentrasi pemberian BAP yang terdiri atas empat taraf, yakni 0, 5, 10, dan $15 \mathrm{ppm}$. Dari rancangan percobaan tersebut diperoleh 8 kombinasi perlakuan dan setiap kombinasi terdiri atas 3 ulangan sehingga terdapat 24 unit percobaan. Tiap unit digunakan 20 bibit tanaman sehingga dibutuhkan 480 bibit tanaman untuk okulasi. Data yang diperoleh diuji secara statistik dengan uji F. Jika berbeda nyata, maka dilakukan uji lanjut dengan Duncan's Multiple Range Test (DMRT) pada taraf nyata 5\%.

Pelaksanaan penelitian dimulai dengan menyiapkan BAP sesuai dengan konsentrasi yang telah ditentukan. Cabang yang diambil mata tunasnya untuk batang atas direndam dalam larutan BAP sesuai dengan konsentrasi perlakuan selama 30 menit kemudian dikeringanginkan. Okulasi dilakukan dengan teknik okulasi irisan (chip budding). Batang bawah disayat dan dikelupas dengan ukuran 2$3 \mathrm{~cm}$. Segera setelah itu, mata tunas dari tanaman batang atas diambil dengan ukuran

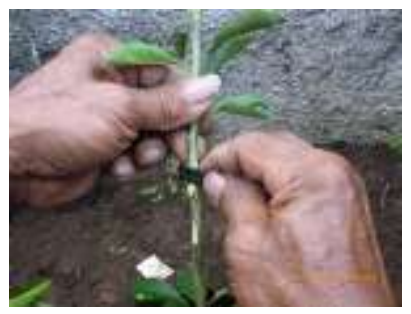

(a.)

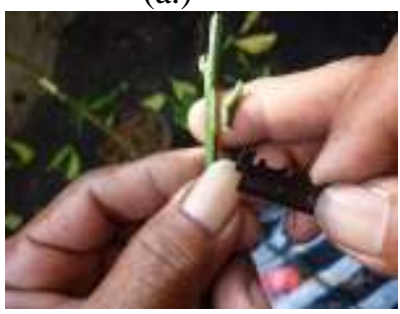

(d.)

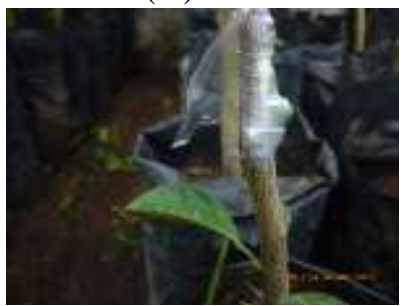

(g.)

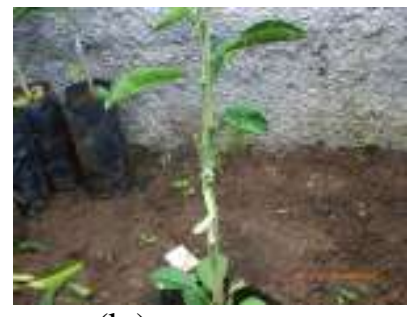

(b.)

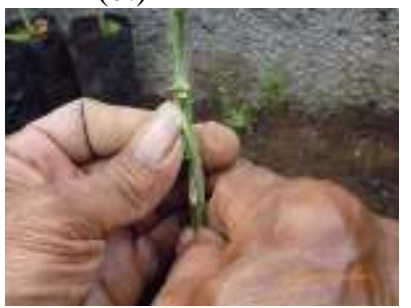

(e.)

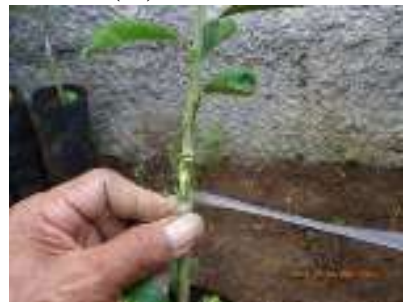

(h.) sayatan lebih kecil atau sama dengan sayatan pada batang bawah. Mata tunas tersebut kemudian disisipkan pada sayatan kulit batang bawah lalu diikat dengan plastik bening yang telah dipotong menyerupai tali. Pembukaan tali pengikat dan looping (pembengkokan batang bawah) dilakukan setelah okulasi berumur 3 minggu. Perawatan tanaman dilakukan dengan menyiram tanaman minimal 3 kali dalam seminggu dan membuang tunas yang tumbuh selain dari mata tunas okulasi. Pemberian insektisida juga diberikan untuk mengendalikan hama yang menyerang tanaman.

Pengamatan dilakukan setelah tali pengikat okulasi dibuka yaitu pada 3 minggu setelah okulasi (MSO), pada perameter keberhasilan okulasi dan pertumbuhan tunas. Parameter keberhasilan okulasi yang diamati pada penelitian ini mencakup persentase okulasi jadi, waktu mencapai $50 \%$ tumbuh tunas, persentase okulasi dorman dan persentase okulasi mati.

Gambar 1. Langkah-langkah okulasi irisan. (a.) menyayat dan mengelupas kulit batang bawah, (b.) kulit batang bawah yang telah dikelupas, (c.) menyayat mata tunas dari batang atas, (d.) mata tunas, (e.) menyisipkan mata tunas ke sayatan pada batang bawah, (f.) mata tunas yang telah disisipkan, (g.) mengikat okulasi dengan plastik bening, (h.) hasil okulasi, (i.) hasil okulasi yang bertunas 
Parameter pertumbuhan tunas yang diamati adalah jumlah okulasi tumbuh, panjang tunas, jumlah daun pada tunas, diameter tunas dan luas daun tanaman. Pengamatan dilakukan setiap 3 hari kecuali untuk parameter persentase okulasi dorman dan okulasi mati dilakukan pada akhir pengamatan. Luas daun diukur pada 10 daun contoh dengan metode gravimetri kemudian membandingkan luas daun dengan panjang dan lebar daun untuk memperoleh nilai konstanta.

\section{HASIL DAN PEMBAHASAN}

\section{Keberhasilan Okulasi}

Penelitian ini menunjukkan bahwa pemberian BAP dan perbedaan varietas batang atas memberikan pengaruh yang tidak nyata terhadap keberhasilan okulasi jeruk keprok. Interaksi antara konsentrasi BAP dan varietas batang atas juga tidak berpengaruh nyata terhadap keberhasilan okulasi. Pemberian BAP dengan beberapa konsentrasi pada dua varietas batang atas menunjukkan nilai yang tidak berbeda nyata terhadap 4 parameter keberhasilan okulasi, yakni persentase okulasi jadi, waktu mencapai $50 \%$ tumbuh tunas, persentase bibit dorman, dan persentase bibit mati. Penggunaan varietas interstock (batang antara) yang berbeda menunjukkan respon pertumbuhan bagian atas jeruk Pamelo 'Nambangan' yang berbeda (Susanto et al., 2010).
Hasil uji lanjut (Tabel 1) menunjukkan bahwa pemberian BAP belum memberikan hasil yang baik pada keberhasilan okulasi tanaman jeruk keprok. Persentase okulasi jadi pada saat plastik penutup dibuka (21 HSO) berkisar antara 83.33-90.83\% (Tabel 1). Hasil penelitian menunjukkan bahwa diberi atau tidak diberi BAP persentase okulasi yang berhasil telah tinggi yakni di atas $80 \%$.

Okulasi yang dilakukan pada dua varietas batang atas yang berbeda menunjukkan hasil yang tidak berbeda nyata. Hal ini berarti bahwa perbedaan varietas batang atas tidak mempengaruhi keberhasilan okulasi. Hasil penelitian yang menunjukkan bahwa persentase keberhasilan okulasi pada varietas Garut Dataran Rendah lebih tinggi mengindikasikan bahwa keprok Garut Dataran Rendah mempunyai kompatibilitas dengan batang bawah (RL) yang lebih tinggi dibanding varietas keprok Borneo Prima. Yusran dan Noer (2011) menyatakan bahwa kompatibilitas okulasi juga ditentukan oleh kondisi antara batang bawah dan batang atas dalam mempermudah pertautan. Batang yang dalam keadaan mudah dikelupas kulitnya atau meristemnya sedang aktif membelah akan lebih mudah menyatu sehingga memberikan tingkat keberhasilan okulasi yang lebih tinggi.

Keberhasilan pada okulasi sangat dipengaruhi oleh berbagai faktor antara lain adalah kondisi materi perbanyakan, kondisi lingkungan tumbuh dan keterampilan pelaksana (Setiono dan Supriyanto, 2004).

Tabel 1. Persentase okulasi jadi pada pengamatan pada konsentrasi BAP dan varietas batang atas yang berbeda

\begin{tabular}{lcccccc}
\hline \multirow{2}{*}{ Perlakuan } & \multicolumn{6}{c}{ Umur Bibit Okulasi (HSO) } \\
& 21 & 28 & 46 & 64 & 82 & 100 \\
\hline & $\ldots \ldots \ldots \ldots \ldots \ldots \ldots . . P e r s e n t a s e$ & Okulasi Jadi $(\%) \ldots \ldots \ldots \ldots \ldots \ldots \ldots \ldots \ldots \ldots \ldots \ldots$ \\
Konsentrasi BAP & & & & & & \\
$0 \mathrm{ppm}$ & 90.83 & 90.00 & 90.00 & 85.00 & 75.83 & 55.00 \\
$5 \mathrm{ppm}$ & 86.67 & 83.33 & 81.67 & 76.67 & 65.83 & 53.33 \\
$10 \mathrm{ppm}$ & 83.33 & 82.50 & 80.83 & 80.00 & 70.83 & 55.00 \\
$15 \mathrm{ppm}$ & 85.83 & 81.67 & 80.83 & 80.00 & 65.83 & 55.00 \\
Varietas Batang Atas & & & & & & \\
Garut Dataran Rendah & 89.17 & 87.50 & 85.83 & 82.50 & 72.08 & 58.75 \\
Borneo Prima & 84.17 & 81.25 & 80.83 & 78.33 & 67.08 & 50.42 \\
\hline KK (\%) & 13.19 & 13.77 & 12.22 & 14.55 & 16.86 & 24.51 \\
\hline
\end{tabular}


Kondisi optimal semaian batang bawah untuk diokulasi adalah batang yang sedang mengalami pertumbuhan aktif (tumbuhnya tunas baru dan kulit batangnya mudah dikelupas) dengan diameter batang yang tidak terlalu kecil. Mata tunas yang hendak digunakan sebaiknya berasal dari Blok Penggandaan Mata Tempel (BPMT), karena telah terjamin kemurnian varietas, kesehatan dan mutunya. Lingkungan tumbuh yang optimal diperlukan untuk proses penyembuhan luka jaringan mata tempel dan semaian batang bawah. Keterampilan pelaksana okulasi menjadi faktor penting pada kegiatan okulasi karena berkaitan dengan pemilihan teknik okulasi yang sesuai, efisiensi waktu, tenaga dan biaya.

Setiono dan Supriyanto (2004) menyatakan bahwa lingkungan tumbuh yang optimal diperlukan untuk proses penyembuhan luka jaringan mata tempel dan semaian batang bawah. Oksigen, suhu, dan kelembaban mempunyai peran penting dalam mengatur prose penyatuan jaringan. Kebutuhan oksigen dapat dipenuhi dengan cara pengikatan okulasi yang tidak terlalu kencang, suhu optimal berkisar antara $20-30{ }^{\circ} \mathrm{C}$, kelembaban udara dipertahankan diatas 70\%. Sutami et al. (2009) menyatakan hal yang sama bahwa suhu dan kelembaban sangat berperan dalam proses pertautan antara batang bawah dan entris. Hartman dan Kester (1983) menyatakan bahwa suhu udara berpengaruh terhadap pembentukan sel sel parenkim penyusun jaringan kalus yang terbentuk akibat adanya perlukaan (irisan). Suhu optimum 27-29 ${ }^{\circ} \mathrm{C}$, suhu lebih tinggi dari $29{ }^{\circ} \mathrm{C}$ menyebabkan pembentukan sel-sel parenkim berlebihan, tetapi dinding selnya tipis sehingga mudah rusak. Pada suhu dibawah $20{ }^{\circ} \mathrm{C}$, pembentukkan kalus lambat dan di bawah $15{ }^{\circ} \mathrm{C}$ kalus sama sekali tidak akan terbentuk.

Selama periode pengamatan, persentase okulasi jadi terus mengalami penurunan (Tabel 1). Penurunan yang terjadi nilainya relatif sama yakni berkisar antara $25-35 \%$. Selama pengamatan terdapat beberapa bibit atau tunas yang mati. Adapun penyebab matinya bibit hasil okulasi tersebut diantaranya adalah perawatan tanaman yang kurang baik sehingga kebutuhan air dan unsur hara kurang tercukupi. Selain itu terdapat beberapa hama dan penyakit yang menyerang bibit okulasi Hama yang menyerang bibit okulasi antara lain ulat, belalang, dan bekicot. Ulat yang menyerang bibit okulasi adalah jenis ulat peliang daun (Phyllocnistis citrella). Ulat ini menyerang bagian daun muda tanaman. Gejala yang timbul adalah adanya alur melingkar transparan atau keperakan, tunas atau daun muda mengkerut, menggulung, dan rontok. Penyakit yang menyerang bibit okulasi adalah busuk akar dan pangkal batang. Penyakit ini disebabkan oleh jamur Phyrophthora nicotianae. Bagian yang diserang adalah akar dan pangkal batang. Gejala yang timbul yakni bagian bawah tanaman kering yang selanjutnya menyebabkan bibit mati. Menurut Prastowo dan Roshetko (2006) ada beberapa hal yang perlu dilakukan dalam upaya pemeliharaan bibit setelah okulasi.

Penyiraman dilakukan paling lama 2 hari sekali karena tanaman yang ditempel mengalami pelukaan/stress sehingga membutuhkan makanan, air, dan perawatan yang baik. Pemupukan tanaman dapat dilakukan pada seminggu sekali. Penyemprotan insektisida dapat dilakukan apabila terdapat hama yang menyerang tanaman. Penyemprotan dengan fungisida apabila terdapat serangan penyakit lodoh/busuk daun, gejala bercak-bercak hitam pada permukaan daun, daun melipat dan melekat satu sama lainnya, selanjutnya daun menjadi kecoklatan, kering dan mati. Biasanya penyakit yang menyerang tanaman di pembibitan terutama yang disebabkan oleh Rhizoctonia sp, Phytophthora sp, Fusarium sp dan Phytium sp.

Pertumbuhan pada okulasi dimulai dengan adanya pertautan antara batang atas dan batang bawah, selanjutnya terbentuk tunas yang mengawali perubahan bentuk tanaman menjadi individu baru. Waktu mencapai 50\% tumbuh tunas (Tabel 2) merupakan salah satu indikasi adanya pertumbuhan tanaman.

Hasil penelitian menunjukkan bahwa pemberian BAP pada okulasi memberikan pengaruh yang berbeda tidak nyata terhadap waktu mencapai $50 \%$ tumbuh tunas. Hal ini dapat diduga konsentrasi BAP yang diberikan terlalu rendah, sehingga belum mampu memacu pertumbuhan tunas. Bibit hasil okulasi mencapai 50\% tumbuh tunas pada kisaran 47-51 hari setelah okulasi dilakukan. 
Tabel 2. Waktu mencapai 50\% tumbuh tunas, persentase bibit dorman, persentase bibit mati pada konsentrasi BAP dan varietas batang atas yang berbeda

\begin{tabular}{lccc}
\hline Perlakuan & $\begin{array}{c}\text { Waktu 50\% Tumbuh } \\
\text { Tunas (Hari) }\end{array}$ & $\begin{array}{c}\text { Persentase Dorman } \\
(\%)\end{array}$ & $\begin{array}{c}\text { Persentase Mati } \\
(\%)\end{array}$ \\
\hline Konsentrasi BAP & & & \\
$0 \mathrm{ppm}$ & 47.7 & 3.3 & 45.0 \\
$5 \mathrm{ppm}$ & 52.0 & 3.3 & 46.7 \\
$10 \mathrm{ppm}$ & 48.8 & 4.2 & 45.0 \\
$15 \mathrm{ppm}$ & 50.5 & 2.5 & 45.0 \\
Varietas Batang Atas & & & \\
Garut Dataran Rendah & 50.4 & 4.2 & 41.3 \\
Borneo Prima & 49.0 & 2.5 & 49.6 \\
\hline
\end{tabular}

Salisbury dan Cleon (1992) menyatakan bahwa BAP mampu memacu perkembangan kloroplas dan sintesis klorofil. BAP akan merangsang pecahnya seludang tunas dan tumbuhnya mata tunas, serta mencegah dominansi apikal yang menghambat pertumbuhan tunas samping. Hal ini mengindikasikan bahwa pemberian BAP seharusnya mampu mempercepat pertumbuhan tunas. Namun, pada penelitian ini pemberian BAP belum mampu menunjukkan hal tersebut.

Bibit dorman merupakan kondisi ketika mata tunas okulasi masih dalam keaadan hijau namun belum atau tidak dapat berkembang menjadi tunas tanaman. Pada penelitian ini, persentase bibit okulasi yang dorman berkisar antara 2.5-4.17\% (Tabel 2) dan tidak dipengaruhi oleh konsentrasi BAP. Persentase bibit dorman yang terdapat pada bibit okulasi dari dua varietas batang atas yang berbeda juga memberikan hasil yang tidak berbeda nyata. Sunaryono (1984) menyatakan bahwa entress yang masih tidur atau dorman akan lambat membentuk pertautan dan sukar menuju pecah tunas. Supriyanto (1990) menambahkan entress yang dorman dikaitkan dengan kondisi dorman entress pada pohon induknya.

Tingkat keberhasilan okulasi sangat dipengaruhi oleh banyak faktor baik dari dalam maupun dari luar. Ketepatan dalam menentukan waktu, cara, dan perawatan dalam melaksanakan okulasi akan menekan jumlah okulasi yang mati atau gagal. Berdasarkan hasil analisis statistik, persentase bibit yang mati tidak berbeda nyata antara perlakuan BAP maupun varietas. Hasil penelitian menunjukkan bahwa bibit hasil okulasi yang mati berkisar antara $41-50 \%$ dari jumlah bibit yang digunakan.

Okulasi pada penelitian ini dilakukan pada kondisi semua batang bawah yang digunakan mudah dikelupas kulit batangnya. Hal ini mengindikasikan bahwa pemberian BAP tidak memberikan hasil yang berbeda ketika diaplikasikan pada bibit jeruk yang tengah aktif membelah, yakni kulit batangnya mudah dikelupas. Wudianto (2002) menyatakan waktu untuk melakukan okulasi yang paling baik adalah pada saat kulit batang bawah maupun batang atas mudah dikelupas dari kayunya. Saat ini terjadi pada waktu pembelahan sel dalam kambium berlangsung secara aktif. Setiap pohon mempunyai waktu pembelahan yang berbeda, ada yang aktif di musim kemarau ada pula yang aktif di musim hujan. Faktor-faktor yang mempengaruhi mudah atau sulitnya pelepasan kulit kayu diantaranya adalah curah hujan, pengairan, dan ketinggian tempat. Pada umumnya tanaman mudah dilepas kulit kayunya pada kondisi curah hujan tinggi atau pengairan yang cukup.

\section{Pertumbuhan Tunas Okulasi}

Hasil analisis statistik ini menunjukkan bahwa pemberian BAP dan varietas batang atas tidak berpengaruh nyata terhadap pertumbuhan tunas hasil okulasi. Rata-rata jumlah tunas okulasi yang berhasil tumbuh pada setiap perlakuan tidak berbeda nyata (Tabel 3), meskipun pada keprok Garut Dataran Rendah menunjukkan angka cenderung lebih tinggi dibandingkan keprok dengan Borneo Prima.

Pertumbuhan tunas akan ditandai dengan adanya pertambahan panjang dari tunas yang telah tumbuh (Tabel 4). Dari hasil uji lanjut menunjukkan bahwa pengaruh perlakuan pemberian BAP varietas berbeda tidak nyata. Tunas hasil okulasi mulai tumbuh dan terus bertambah panjang pada bibit berumur 28 HSO. Pertambahan panjang tunas terjadi tidak bersamaan dan tidak seragam. 
Tabel 3. Jumlah okulasi yang tumbuh pada perlakuan konsentrasi BAP dan varietas batang atas yang berbeda

\begin{tabular}{lccccc}
\hline \multirow{2}{*}{ Perlakuan } & \multicolumn{5}{c}{ Umur Bibit Okulasi } \\
\cline { 2 - 6 } & $28 \mathrm{HSO}$ & 37 HSO & 46 HSO & $73 \mathrm{HSO}$ & $100 \mathrm{HSO}$ \\
\hline Konsentrasi BAP & $\ldots \ldots \ldots \ldots \ldots \ldots$. Jumlah Tunas Okulasi Tumbuh................. \\
$0 \mathrm{ppm}$ & 0.67 & 5.50 & 9.17 & 13.67 & 10.33 \\
$5 \mathrm{ppm}$ & 1.17 & 6.33 & 8.17 & 12.17 & 10.00 \\
$10 \mathrm{ppm}$ & 2.00 & 5.67 & 8.17 & 11.67 & 10.17 \\
$15 \mathrm{ppm}$ & 2.33 & 6.67 & 8.50 & 12.67 & 10.50 \\
Varietas Batang Atas & & & & & \\
Garut Dataran Rendah & 2.08 & 6.75 & 8.75 & 13.17 & 10.92 \\
Borneo Prima & 1.00 & 5.33 & 8.25 & 11.92 & 9.58 \\
\hline
\end{tabular}

Tabel 4. Panjang tunas okulasi, jumlah daun pada tunas, dan diameter tunas okulasi pada perlakuan konsentrasi BAP dan varietas batang atas yang berbeda

\begin{tabular}{|c|c|c|c|c|c|}
\hline \multirow{2}{*}{ Perlakuan } & \multicolumn{5}{|c|}{ Umur Tanaman } \\
\hline & $28 \mathrm{HSO}$ & $46 \mathrm{HSO}$ & $64 \mathrm{HSO}$ & $82 \mathrm{HSO}$ & $100 \mathrm{HSO}$ \\
\hline & \multicolumn{5}{|c|}{ 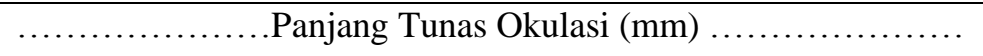 } \\
\hline \multicolumn{6}{|l|}{ Konsentrasi BAP } \\
\hline $0 \mathrm{ppm}$ & 0.11 & 16.44 & 33.39 & 57.50 & 91.72 \\
\hline $5 \mathrm{ppm}$ & 0.11 & 19.83 & 37.72 & 63.00 & 86.17 \\
\hline $10 \mathrm{ppm}$ & 0.56 & 26.22 & 39.00 & 56.17 & 69.61 \\
\hline $15 \mathrm{ppm}$ & 0.56 & 22.39 & 42.67 & 55.83 & 73.39 \\
\hline \multicolumn{6}{|l|}{ Varietas Batang Atas } \\
\hline Garut Dataran rendah & 0.36 & 22.83 & 39.50 & 64.33 & 90.25 \\
\hline \multirow[t]{2}{*}{ Borneo Prima } & 0.31 & 19.61 & 36.89 & 51.92 & 70.19 \\
\hline & \multicolumn{5}{|c|}{..............Jumlah Daun pada Tunas Okulasi (helai) .............. } \\
\hline \multicolumn{6}{|l|}{ Konsentrasi BAP } \\
\hline $0 \mathrm{ppm}$ & 0 & $3.00 \mathrm{ab}$ & 5.94 & 6.06 & $11.33 \mathrm{a}$ \\
\hline $5 \mathrm{ppm}$ & 0 & $3.17 \mathrm{ab}$ & 4.33 & 6.94 & $8.67 \mathrm{ab}$ \\
\hline $10 \mathrm{ppm}$ & 0.69 & $4.28 \mathrm{a}$ & 4.72 & 6.22 & $8.11 \mathrm{ab}$ \\
\hline $15 \mathrm{ppm}$ & 0.28 & $1.67 \mathrm{~b}$ & 5.39 & 6.67 & $6.28 b$ \\
\hline \multicolumn{6}{|l|}{ Varietas Batang Atas } \\
\hline Garut Dataran Rendah & 0.28 & 2.97 & 5.42 & 7.06 & 9.22 \\
\hline \multirow[t]{2}{*}{ Borneo Prima } & 0.06 & 3.08 & 4.78 & 5.89 & 7.97 \\
\hline & \multicolumn{5}{|c|}{$\ldots \ldots \ldots \ldots \ldots \ldots \ldots$ Diameter Tunas Okulasi $(\mathrm{mm}) \ldots \ldots \ldots \ldots \ldots \ldots \ldots \ldots \ldots$} \\
\hline \multicolumn{6}{|l|}{ Konsentrasi BAP } \\
\hline $0 \mathrm{ppm}$ & 0 & 0.58 & 1.33 & 2.32 & 2.59 \\
\hline $5 \mathrm{ppm}$ & 0 & 0.67 & 1.56 & 2.32 & 2.51 \\
\hline $10 \mathrm{ppm}$ & 0 & 1.11 & 1.58 & 2.11 & 2.33 \\
\hline $15 \mathrm{ppm}$ & 0 & 0.81 & 1.72 & 2.14 & 2.40 \\
\hline \multicolumn{6}{|l|}{ Varietas Batang Atas } \\
\hline Garut Dataran Rendah & 0 & 0.92 & 1.65 & 2.41 & 2.67 \\
\hline Borneo Prima & 0 & 0.67 & 1.44 & 2.04 & 2.24 \\
\hline
\end{tabular}


Pertumbuhan tunas diikuti dengan pertumbuhan daun pada tunas. Hasil analisis statistik menunjukkan bahwa jumlah daun pada bibit berumur 46 HSO dan 100 HSO berbeda nyata. Okulasi yang diberi BAP dengan konsentrasi $10 \mathrm{ppm}$ memiliki jumlah daun paling banyak pada umur 46 HSO yakni sebanyak 4.28 helai (5 helai). Pada bibit umur 100 HSO jumlah daun paling banyak terdapat pada bibit okulasi yang tidak diberi BAP yakni sebanyak 11.3 helai (12 helai). Hal ini sejalan dengan panjang tunas okulasi.

Jumlah daun erat hubungannya dengan panjang tunas. Banyaknya daun pada tunas perbibit disebabkan pertumbuhan tunas yang baik. Semakin panjang tunas semakin banyak daun yang dihasilkan. Jumlah daun akan bertambah seiring dengan panjang tunas, karena tunas yang lebih panjang menyebabkan bertambahnya jumlah ruas dan buku tempat tumbuhnya daun (Karnedi, 1998).

Perbedaan konsentrasi BAP pada okulasi tanaman jeruk tidak berpengaruh nyata terhadap diameter tunas okulasi. Berdasarkan hasil analisis menunjukkan bahwa pemberian BAP dengan konsentrasi $10 \mathrm{ppm}$ mendominasi pada awal pengamatan yaitu sebesar $1.11 \mathrm{~mm}$, namun nilai tersebut berbeda tidak nyata dengan perlakuan pemberian BAP dengan konsentrasi lainnya. Varietas keprok Garut Dataran Rendah memiliki diameter tunas yang lebih besar daripada keprok Borneo Prima, namun secara statistik tidak berbeda nyata.

Berdasarkan pertumbuhan tunas hasil okulasi, terdapat kecenderungan pemberian BAP mampu memacu pertumbuhan tunas okulasi sampai tanaman berumur sekitar 1.5 bulan. Hal ini menunjukkan bahwa BAP bertahan dalam jaringan tanaman selama 1.5 bulan kemudian BAP dapat diberikan secara berkala seperti pada penelitian Karintus (2011), BAP diaplikasikan pada okulasi karet setiap 2 minggu sekali.

Pertumbuhan tunas akan terjadi setelah adanya pertautan antara batang atas dengan batang bawah. Hartman dan Kester (1983) menyatakan bahwa pertautan antara batang atas dengan batang bawah diawali oleh terbentuknya lapisan nekrotik pada permukaan sambungan yang membantu menyatukan jaringan sambungan terutama di dekat berkas vaskular. Pemulihan luka dilakukan oleh selsel meristematik yang terbentuk antara jaringan yang tidak terluka dengan lapisan nekrotik. Lapisan nekrotik ini kemudian menghilang dan digantikan oleh kalus yang dihasilkan oleh sel-sel parenkim, sel-sel parenkim dari batang atas dan batang bawah masing-masing saling kontak, menyatu dan selanjutnya membaur. Sel-sel parenkim yang terbentuk akan terdeferensiasi membentuk lapisan kambium sebagai lanjutan dari lapisan kambium batang atas dan batang bawah yang lama, selanjutnya dari lapisan kambium akan terbentuk jaringan pembuluh sehingga proses translokasi hara dari batang bawah ke batang atas dan sebaliknya untuk hasil fotosintesis dapat berlangsung kembali. Penyatuan dua jaringan hanya mungkin jika kedua jenis tanaman cocok (kompatibel) dan irisan luka rata, serta pengikatan sambungan tidak terlalu lemah dan tidak terlalu kuat sehingga tidak terjadi kerusakan jaringan.

BAP diberikan pada okulasi dengan maksud untuk meningkatkan pembelahan sel tanaman. Pada saat sulit, kambium tanaman tidak aktif membelah yang ditandai dengan batang sulit dikelupas, pemberian BAP diharapkan mampu meningkatkan tunas yang jadi. Penelitian menunjukkan bahwa diberi atau tidak diberi BAP hasilnya sama saja. Hal ini dapat mengindikasikan bahwa tanaman dalam kondisi kambium yang sedang aktif membelah sehingga pemberian BAP tidak terlalu berpengaruh.

Luas daun jeruk keprok Garut Dataran Rendah dan keprok Borneo Prima relatif sama. Berdasarkan hasil perhitungan substitusi rumus luas daun dengan metode gravimetri terhadap panjang dan lebar daun diperoleh nilai konstanta sebesar 0.6899456. Semakin banyak angka desimal di belakang koma maka perhitungan luas daun pun akan semakin akurat. Hal yang berbeda dilaporkan oleh Susanto et al. (2010) penggunaan varietas interstok (batang antara) yang berbeda menunjukkan respon pertumbuhan batang atas jeruk pamelo "Nambangan" yang berbeda. 
J. Hort. Indonesia 5(3):158-167. Desember 2014.

Tabel 5. Luas daun varietas Keprok Garut

\begin{tabular}{ccclrrc}
\hline Daun Ke- & Panjang $(\mathrm{cm})$ & Lebar $(\mathrm{cm})$ & Bobot $(\mathrm{g})$ & $\mathrm{LD}\left(\mathrm{cm}^{2}\right)$ & PxL & $\mathrm{K}$ \\
\hline Sampel & 10.00 & 10.00 & 0.75 & 100.00 & 100.00 & \\
1 & 9.00 & 4.50 & 0.22 & 29.33 & 40.50 & 0.7242798 \\
2 & 8.20 & 4.00 & 0.18 & 24.00 & 32.80 & 0.7317073 \\
3 & 6.10 & 3.10 & 0.09 & 12.00 & 18.91 & 0.6345849 \\
4 & 7.60 & 3.90 & 0.15 & 20.00 & 29.64 & 0.6747638 \\
5 & 7.10 & 4.20 & 0.15 & 20.00 & 29.82 & 0.6706908 \\
6 & 8.10 & 4.20 & 0.17 & 22.67 & 34.02 & 0.6662747 \\
7 & 6.80 & 3.00 & 0.10 & 13.33 & 20.40 & 0.6535948 \\
8 & 8.30 & 4.40 & 0.18 & 24.00 & 36.52 & 0.6571742 \\
9 & 6.10 & 2.80 & 0.09 & 12.00 & 17.08 & 0.7025761 \\
10 & 6.30 & 4.30 & 0.15 & 20.00 & 27.09 & 0.7382798 \\
\hline Rata-Rata & 7.36 & 3.84 & 0.148 & 19.73 & 28.68 & 0.6853926 \\
\hline
\end{tabular}

Keterangan: $\mathrm{P}=$ panjang daun, $\mathrm{L}=$ lebar daun, $\mathrm{LD}=$ luas daun, $\mathrm{K}=$ konstanta

Tabel 6. Luas daun varietas Keprok Borneo Prima

\begin{tabular}{ccclrrc}
\hline Daun Ke- & Panjang $(\mathrm{cm})$ & Lebar $(\mathrm{cm})$ & Bobot $(\mathrm{g})$ & $\mathrm{LD}\left(\mathrm{cm}^{2}\right)$ & PxL & $\mathrm{K}$ \\
\hline Sampel & 10.00 & 10.00 & 0.75 & 100.00 & 100.00 & \\
1 & 8.50 & 4.20 & 0.20 & 26.67 & 35.70 & 0.7469655 \\
2 & 5.20 & 3.10 & 0.09 & 12.00 & 16.12 & 0.7444169 \\
3 & 7.00 & 3.30 & 0.12 & 16.00 & 23.10 & 0.6926407 \\
4 & 7.00 & 3.40 & 0.12 & 16.00 & 23.80 & 0.6722689 \\
5 & 6.20 & 3.10 & 0.11 & 14.67 & 19.22 & 0.763094 \\
$\mathrm{~s} 6$ & 6.60 & 3.50 & 0.11 & 14.67 & 23.10 & 0.6349206 \\
7 & 7.10 & 3.40 & 0.12 & 16.00 & 24.14 & 0.6628003 \\
8 & 6.50 & 3.20 & 0.11 & 14.67 & 20.80 & 0.7051282 \\
9 & 7.20 & 3.50 & 0.13 & 17.33 & 25.20 & 0.6878307 \\
10 & 6.00 & 2.80 & 0.08 & 10.67 & 16.80 & 0.6349206 \\
\hline Rata-Rata & 6.73 & 3.35 & 0.12 & 15.87 & 22.79 & 0.6944986 \\
\hline
\end{tabular}

Keterangan: $\mathrm{P}=$ panjang daun, $\mathrm{L}=$ lebar daun, $\mathrm{LD}=$ luas daun, $\mathrm{K}=$ konstanta

Pertambahan panjang daun dan lebar daun dipengaruhi oleh pembelahan sel yang berlansung secara antiklinal dan periklinal. Panjang daun dan lebar daun yang relatif sama menunjukkan tingkat pembelahan secara periklinal dan antiklinal relatif seimbang (Lakitan, 2004).

\section{KESIMPULAN}

Pemberian Benzil amino purin (BAP) dengan teknik perendaman batang atas memberikan hasil yang tidak nyata pada okulasi jeruk keprok varietas Borneo Prima dan Garut Dataran Rendah. Pemberian BAP pada okulasi dengan konsentrasi yang rendah belum mampu meningkatkan keberhasilan okulasi dan memacu pertumbuhan tunas hasil okulasi.

\section{SARAN}

Penelitian berikutnya disarankan menggunakan zat pengatur tumbuh jenis lain atau dengan konsentrasi BAP yang lebih tinggi dan dikombinasikan dengan ZPT lainnya. Metode dalam pemberian BAP pada okulasi juga perlu dikaji ulang agar memperoleh hasil okulasi yang maksimal. Selain itu, penelitian dapat juga dilakukan menggunakan batang bawah dengan varietas yang lain.

\section{DAFTAR PUSTAKA}

[BPS] Badan Pusat Statistik. 2013. Produksi buah-buahan dan sayuran tahunan di Indonesia, 1995-2013. http://www.bps. go.id/tab_sub/view.php?kat=3\&tabel=1 $\&$ daftar $=1 \&$ id_subyek $=55 \&$ notab $=15$. [10 Juli 2014]. 
Direktorat Jenderal Hortikultura. 2011. Informasi ringkas jeruk. Tersedia pada: http://pusdatin.setjen.pertanian.go.id/pu blikasi-183-informasi-ringkas-jeruk. html. [10 Juli 2014].

Hardiyanto. 2012. Mampukah jeruk keprok nasional kita menggeser jeruk impor? http://balitjestro.litbang.deptan.go.id/id/ 374.html. [20 November 2012].

Hartman, H.T., D.F. Kester. 1983. Plant Propagation, Principles and Practices. Fourth Edition. Prentice-Hall International, Inc. New Jersey.

Karnedi. 1998. Pengaruh Konsentrasi Urine Sapi Terhadap Pertumbuhan Bibit Panili (Vanila planifolia Andrew). Skripsi. Fakultas Pertanian Universitas Andalas. 54 Hal. Padang.

Karintus. 2011. Pengaruh macam entres dan konsentrasi BAP pada pertumbuhan okulasi karet (Hevea brasiliensis Muell Arg). Skripsi. Universitas Sebelas Maret. Surakarta.

Lakitan, B. 2004. Hortikultura: Teori, Budidaya dan Pasca Panen. Rajawali Pr. 219 hal. Jakarta.

Poerwanto, R, dkk. 2013. Pengembangan Jeruk Unggulan Indonesia Guna Pemenuhan Kebutuhan Gizi Masyarakat dan Penghematan Devisa Negara Tahun II. Makalah Semiloka Nasional. 7-8 November 2013. Hal. 543-552. Jakarta.

Prastowo, N., J.M. Roshetko. 2006. Tehnik Pembibitan dan Perbanyakan Vegetatif Tanaman Buah. World Agroforestry Centre (ICRAF) dan Winrock International. Bogor, Indonesia. p. 100. Bogor.
Salisbury, F.B., W.R. Cleon. 1992. Fisiologi Tumbuhan. Diah, R.D., Sumaryono, penerjemah. ITB Pr. Terjemahan dari: Plant Physiology. Bandung.

Setiono, A. Supriyanto. 2004. Keunggulan teknik perbanyakan okulasi irisan pada tanaman jeruk. Malang: Loka Penelitian Tanaman Jeruk dan Hortikultura Subtropik-Tlekung.

Sunaryono, H. 1984. Ilmu Produksi Tanaman Buah-buahan. CV. Sinar Baru. Hal. 2030. Bandung.

Supriyanto, A. 1990. Pengelolaan Pembibitan Jeruk Bebas Penyakit dalam Kantong Plastik. Denpasar: Sub Balai Penelitian Hortikultura Tlekung. 15 hal.

Susanto, S., H. Sugeru, S. Minten. 2010. Pertumbuhan vegetatif dan generatif batang atas jeruk Pamelo 'Nambangan' pada empat jenis interstok. J. Hort. Indonesia. 1(2): 53-58.

Sutami, M. Athahillah, M.S.N. Gusti. 2009. Pengaruh umur batang bawah dan panjang entris terhadap keberhasilan sambungan bibit jeruk siam Banjar Label Biru. http://faperta.unlam.ac.id/ web/wpcontent/uploads/downloads/201 2/02/Sutami-9.pdf. [6 Oktober 2013].

Sutopo. 2012. Kelemahan revitalisasi jeruk nasional. http://balitjestro.litbang.deptan. go.id/id/500.html. [20 November 2012].

Wudianto, R. 2002. Cara Membuat Setek, Cangkok dan Okulasi. Penebar Swadaya. Jakarta.

Yusran, A.H. Noer. 2011. Keberhasilan okulasi varietas jeruk manis pada berbagai perbandingan pupuk kandang Skripsi. Fakultas Pertanian Universitas Tadulako Palu. Makassar. 